\title{
Entering the digital era of the Open Skies Treaty
}

\author{
Agata Orych \\ Military University of Technology \\ Faculty of Geodesy and Civil Engineering \\ Geodesy Institute, Department of Remote Sensing and Photogrammetry \\ 2 Kaliskiego Street, 00-908 Warsaw, Poland \\ agata.orych@wat.edu.pl
}

Received: 8 April 2015 / Accepted: 24 April 2015

\begin{abstract}
The Open Skies Treaty has been a peace-building instrument between North American and European nations for over two decades. This agreement is based on the possibility for each country-signatory of the Treaty to independently conduct observation flights and obtain aerial imagery data of the territories of other Treaty States-Parties. This imagery data was originally acquired only using traditional photographic film cameras. Together with the rapid development and advancement of digital sensor technologies, the logical step forward was to amend the Treaty provisions to allow for the use of these types of sensors during observation missions. This paper describes this transition process and highlights a number of technical problems which needed to be addressed by experts working within the Open Skies Consultative Commission workgroups.
\end{abstract}

Keywords: Open Skies Treaty, Digital sensors, spatial resolution

\section{Introduction}

The Treaty on Open Skies is an international agreement between 34 States-Parties, the main aim of which is to strengthen mutual openness and transparency between its signatories from a military point of view. The Treaty is based on the possibility for all States-Parties to independently conduct observation flights over the territories of other States-Parties. Imagery data acquired during such missions can be used to obtain information about the armed forces of the observed territories and to verify their status and numbers with reference to international disarmament treaties. These missions however have to be conducted in accordance with strict rules and regulations, using procedures described within the Treaty and it's Decisions.

\subsection{History of the Treaty}

The concept of an Open Skies agreement was first proposed during the Geneva Summit in 1955, where general Dwight David Eisenhower, the president of the United States, 
proposed a bilateral agreement between them and the USSR for conducting mutual aerial inspections. At this time, the Soviet Government rejected this proposal and the idea was abandoned. This prompted the US to utilize other, one-sided, means of obtaining imagery information of the USSR territories using the U-2 reconnaissance airplane. In the 1960's, when satellite technology came into common use, these two nations regularly conducted reconnaissance flights over each other using space-borne sensors. Such practices were of course considered illegal and could be regarded as typical spying. Data obtained from such sources was not officially reported to the observed country, nor was it made available to them.

The situation in Europe and Northern America at the end of the 1980's created a favourable political climate for renewing talks about a multi-national agreement about legal aerial inspections between its partners. These talks were once again initiated by the United States of America. In 1989 president George Bush proposed a new Open Skies Treaty based on the original idea from 1955, but this time involving not only the USA and USSR but also NATO countries, and countries of the Warsaw Pact. At such a turbulent time of political change, especially in Europe, an agreement giving nations a tool to control military activities and at the same time prevent any military aggression was seen in a very positive light by all above mentioned nations, including the USSR.

The next three years consisted of talks between interested States-Parties to design the fundamental rules and procedures which would ensure the effective fulfilment of this Treaty. On March $24^{\text {th }} 1992,24$ heads of MoD signed the Treaty on Open Skies in Helsinki. The 24 original signatories were: the Federal Republic of Germany, the United States of America, the Republic of Belarus, the Russian Federation, the Kingdom of Belgium, the Republic of Bulgaria, Canada, the Kingdom of Denmark, the Kingdom of Spain, the French Republic, the United Kingdom of Great Britain and Northern Ireland, the Hellenic Republic, the Republic of Hungary, the Republic of Iceland, the Italian Republic, the Grand Duchy of Luxembourg, the Kingdom of the Netherlands, the Kingdom of Norway, the Republic of Poland, the Portuguese Republic, Romania, the Czech and Slovak Federal Republic, the Republic of Turkey and Ukraine. The Treaty entered into force on January $1^{\text {st }} 2002-60$ days after at least 20 of these States-Parties ratified the Treaty in accordance with their respective constitutional procedures. Since Entry Into Force, a number of States-Parties have joined the Treaty on Open Skies, making the current total of signatories 34 nations.

\subsection{Aim}

The Treaty on Open Skies is one of a number of international agreements, the aim of which is to create and sustain a cooperative security system in Europe - the Treaty on Conventional Armed Forces in Europe (CFE), Concluding Act of the Negotiation on Personnel Strength of Conventional Armed Forces in Europe (CFE-1A) and Vienna Document (VD) (Kapuśniak, 2005). 
In accordance with the preamble to the Treaty, it's main aims include:

- promoting greater openness and transparency in the military activities of the Treaty signatories,

- enhancing security by means of confidence- and security-building measures,

- further developing and strengthening peace, stability and cooperative security

- facilitating the monitoring of compliance with existing or future arms control agreements and strengthening the capacity for conflict prevention and crisis management in the framework of the Conference on Security and Co-operation in Europe (OSCE) and in other relevant international institutions (Treaty on Open Skies, 1992).

These aims are met by means of acquiring imagery data of States-Parties' territories during observation flights. Each States-Party has the right to conduct a specific number of observation flights each year over other States-Parties (called the active quota) and also has the obligation to permit any of the Treaty signatories to conduct a specific number of observation flights each year over its own territory (the passive quota). These flights must be conducted in accordance with the provisions of the Treaty and its Decisions. These documents precisely describe not only the procedures which are to be abided by during observation missions, but also regulate the types of equipment which can be used to acquire imagery.

\subsection{Sensors}

During an observation flight imagery can be acquired by means of three different types of sensors: electro optical sensors, infrared sensors and synthetic aperture radar (SAR) sensors. All imagery acquired during Open skies observation missions must comply with one very important limitation - the true spatial resolution of the resulting imagery, or the Ground Resolved distance (GRD), cannot be greater than that defined by the Treaty in Article IV §2. This section of the Treaty limits the maximum obtainable resolution of the sensors to the following values: electro optical sensors $-30 \mathrm{~cm}$, infrared sensors $-50 \mathrm{~cm}$ and SAR sensors $-3 \mathrm{~m}$. Because most of these types of sensors' spatial resolution is directly linked to its height above ground level, each configuration (i.e. a composition of a given sensor, airplane, photosensitive material and additional optics, filters etc) which is to be used during observation missions, has to have a predetermined $\mathrm{H}_{\text {min }}$ value, which is the lowest possible flying altitude at which the maximum obtainable resolution of the sensors is not exceeded. This value is determined by a group of experts from all interested States-Parties on the basis of images of especially designed calibration targets during the certification process. This process is mandatory for all new configurations and encompasses not only the definition of the $\mathrm{H}_{\min }$ value, but also gives experts from all interested States-Parties the opportunity to check whether all elements of the configuration and proposed data processing procedures are in accordance with the Treaty and its Decisions. 
Since Entry into Force, no States-Party has yet certified either an infrared sensor or synthetic aperture radar and therefore up until this day only electro optical sensors are used for acquiring imagery data during Open Skies missions.

Up until mid 2013, the Open Skies Treaty permitted only the use of analogue sensors during observation missions. Data was to be recorded on light sensitive material ("wet film"). This technology and used equipment, sometimes dating back to the 1970's, was sufficient to comply with the rules and regulations of the Treaty. It wasn't until the great advancement of digital sensor technologies on the photographic market that caused major film manufacturers like the Eastman Kodak Company to either limit or completely discontinue the production of film and associated processing chemicals, that this technology had to be rethought by the Open Skies Treaty signatories.

\section{Digital era of Open Skies}

In 2006, the Open Skies Consultative Commission (OSCC) by means of the Informal Working Group on Sensors (IWGS) started work on amending existing Treaty Decisions to enable States-Parties the use of digital imaging sensors for acquiring imagery information during observation missions. This new technology did however bring with it a large number of uncertainties and possible "grey areas" which needed to be addressed by the IWGS. When dealing with traditional "wet film", once the film is exposed and the photographed subject's image is formed on the silver salt crystals and processed into a negative image, there is no way to enhance the spatial resolution of this final image. When working with digital sensors, there are many methods by which the spatial resolution of imagery can be enhanced. These methods include, but are not limited to: image interpolation (Vijayaraghavan et al., 2009), conversion and enhancement using non-increasing operators (Loce et al., 1997), using different demosaicing (or debayering) algorithms (Pulujkar et al., 2013) and spectral shifting (Breitenstein et al., 2010). The experts within the IWGS worked hard for over 7 years, conducting many experiments and analyzing vast numbers of research papers, to enable the use of such sensors during observation missions, ensuring that the spatial resolution of the obtained imagery will never be better than $30 \mathrm{~cm}$, even using currently known image processing techniques. This work resulted in the first digital sensors certification, which was held in September 2013.

\subsection{Work leading towards the adoption of the digital sensor Decisions}

All aspects which differentiate traditional analogue sensors from digital imaging sensors had to be taken into consideration by the IWGS. Some of the most significant discussions included: 
- the type of sensor,

- the spectral resolution,

- technology by which multispectral imagery is acquired,

- visual analysis methodology,

- file formats.

One of the first questions posed to the group was what type of sensor can be utilized during an observation mission. The Decisions describing original electro optical sensors only allowed for the use of framing sensors. Some of the leading digital sensor manufacturers have based their sensors on the pushbroom design, like the Leica ADS80. Such sensors are very effective in the sense that they allow the simultaneous acquisition of a number of spectral bands, all with the same spatial resolution as the panchromatic image (Leica datasheet, 2011). Such sensors however often have the ability to acquire imagery with so-called super-resolution which is the result of data processing from a pair of detector lines which are staggered by half a pixel. Such imagery is characterised by an almost two times better resolution compared to images taken at the same altitude by the remaining detector lines (Reulke et al., 2005). The sensor models analyzed by the IWGS showed no verifiable (physical) means of disabling this mode of data acquisition, therefore after initial experiments, no sensors designed with the intention of providing resolution better than the resolution determined by the size of the detector element (sub pixel resolution) could be used for Open Skies purposes. Further work prompted the IWGS to ban all electro optical line scanners, due to the very advanced, and therefore hard to control, image post-processing which has to take place for all pushbroom sensors in order to obtain geometrically correct images.

The spectral resolution of a sensor determines which bands of the electromagnetic spectrum are registered by the sensor. To give States-Parties the possibility to acquire complete information about the imaged territories, the new digital sensor Decisions allow for the acquisition of panchromatic, RGB and NIR imagery. However, for the purposes of the Treaty, it was necessary to define these spectral bands in a more precise manner. This definition was derived from an analysis of sensors which, at the time of the discussions in early 2008, were most popular on the market for aerial sensors, and included those manufactured by IGI, Intergraph, Jenoptik, Leica, PO KSI, RolleiMetric, Vexcel-Microsoft. The permitted bandwidth of each spectral channel is dependent on the nominal wavelength of that given channel - "for each red, green, or blue spectral band, the bandwidth, $\mathrm{D} \lambda$, of that band shall be greater than 4 times the deviation of the central wavelength of that band, $\lambda_{\text {band }}$, from the nominal wavelength of that band, $\lambda_{\text {nominal }}$., $\mathrm{D} \lambda \geq 4\left|\lambda_{\text {band }}-\lambda_{\text {nominal }}\right|$ ", with the nominal bandwidths for the blue, green and red channels being equal to $0.470,0.547$, and 0.635 micrometers respectively. Infrared sensors are permitted to acquire imagery between 0.690 and 1.100 microns.

When working with framing cameras, multispectral information can be obtained in one of two ways - using a multi-lens sensor or a Bayer pattern sensor. Both of these sensor types have been permitted for use during observation missions, however 
they both required the IWGS experts to evaluate possible problems, that could have an effect on the resolution of final imagery. Multi-lens sensors usually consist of a number of lenses and sensor arrays, that produce sub-images which need to be stitched together to form a final image (Fig. 1). In order to effectively stitch together these sub-images there needs to be a small area of overlap between them.

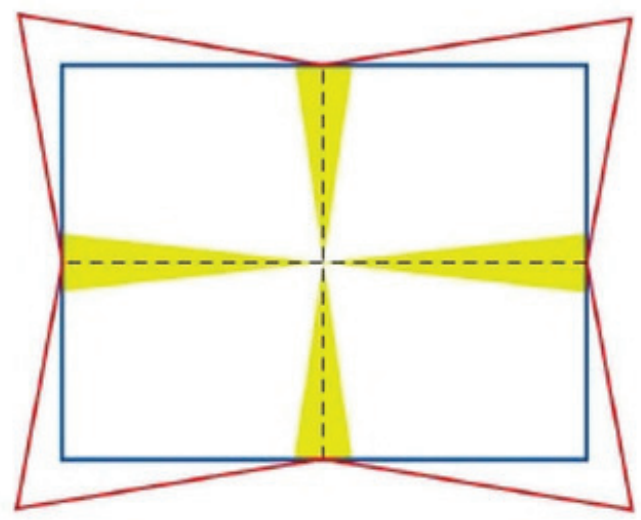

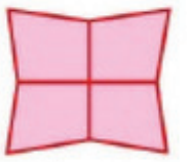

4 images

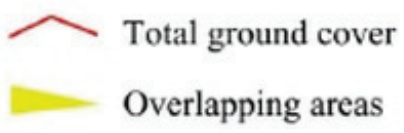

Net ground cover

Fig. 1. Image stitching for imagery obtained by the Intergraph DMC-2001 sensor (Petrie G, 2008)

This raised the question - is the resolution in this stitched area the same as on the remaining area of the final image? The Polish IWGS experts from the Military University of Technology in Warsaw conducted an experiment on digital imagery acquired from a number of different sensors, including the DMC-2001. The conclusions of this experiment were derived from over $2000 \mathrm{H}_{\min }$ results obtained from visual analysis of calibration target imagery. These measurements were taken by almost 110 independent observers. The entire experiment had been described in detail by Orych (2011). Such a large sample of data gave the possibility to conduct a very thorough and credible statistical analysis of these data. These data confirmed, that there is no difference in the spatial resolution between the overlap area of the image and the remaining area of the image. These types of sensors are therefore acceptable by the Treaty.

The second type of multispectral sensor is based on the Bayer filter design, which multispectral information is acquired by a single CCD array, with each pixel "pixels preceded in the optical path by a color filter array (CFA) in a Bayer mosaic pattern" (Malvar et al., 2004). Malvar et al. describe in detail the multitude of different 
demosaicing algorithms which can be used to process a raw Bayer-filter image into a final image, and the affect these algorithms have on the final image. These affects were thoroughly examined by US experts from the IWGS. Their investigations confirmed that this multitude of algorithms is not an issue for Open Skies as they have an insignificant affect on the spatial resolution of resulting imagery.

The experiments described in Orych (2011) were also very useful in determining the most advantageous methodology for conducting visual analysis (VA) of calibration target imagery for Open Skies certification purposes. The parameters that were taken into consideration included: the type of computer monitor on which VA is conducted, the type of graphic card, the resolution of the monitor and using different types of image viewing software to complete this process. These results were also incorporated into the Treaty Decisions.

In order to facilitate an easy to use and reliable exchange of imagery data obtained during observation missions it was necessary to develop a new file extension. The only files which can be retained at the end of an observation mission are OSDDEF files - Open Skies Digital Data Exchange Format files. This is a BIIF file format which includes not only imagery data but also all treaty-required metadata - the observation flight parameters. All other data, both imagery and other ancillary data, must be erased at the end of each mission. Having one common file type makes it easier to control what data is being recorded during the observation flight and also makes the exchange of data easier. Large software companies specializing in remote sensing software are now making it possible to view OSDDEF files directly within their interface, eg Erdas 2014 (Hexagon, 2014).

These, and many other technical issues had to be resolved before it was possible to adopt all essential Treaty Decisions and allow for the first digital sensor certification and first digital sensor Open Skies missions.

\subsection{First digital sensor certification}

During the week 21-27 September 2013 the Russian Federation organized an international certification of their new digital sensor that would be used to acquire digital imagery as part of Open Skies observation missions.

The OSDCAM4060 had been designed and created by Russian company PoKsi (ПО КСИ) especially for the purposes of conducting observation missions and in accordance with Treaty provisions. It is made up of 40 lenses and 60 detector arrays. The detector arrays are sensitive to visible light (RGB) and near-infrared (NIR). The radiometric resolution is equal to12bit. Depending on which sets of lenses and arrays are currently working (or are not covered by special metal covers), the sensor can be used at 3 different altitudes and 4 different configurations.

A total of 58 experts from 22 States-Parties attended the certification. The certification process consisted of: briefings and demonstrations, demonstration flights and acquisition of imagery data for all configurations, an inspection of the aircraft 
and sensors, an inspection of the process of creating OSDDEF files and determining $\mathrm{H}_{\text {min }}$ for each configuration. The Russian certification, being the first digital sensor certification in Open Skies history, was slightly problematic and raised a number of new problems which needed to be promptly addressed by the IWGS. Despite technical problems, the certification was in the end a success and the first observation flight utilizing the OSDCAM 4060 was conducted in July 2014 over the territory of Poland.

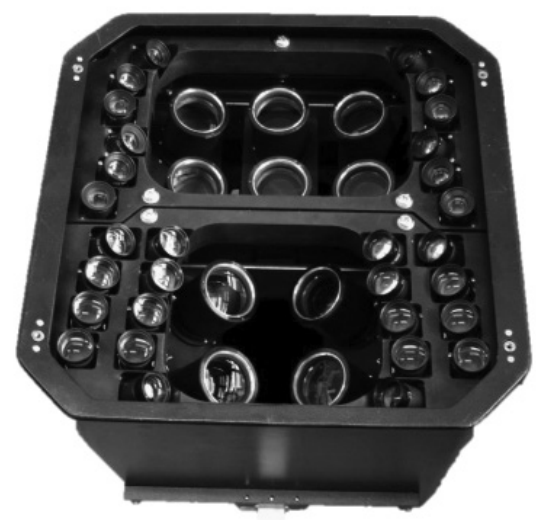

Fig. 2. The Russian OSDCAM 4060 digital sensor

\section{Conclusion - the future of the Open Skies Treaty}

The future sees many Open Skies Treaty States-Parties moving towards the certification of new digital equipment. With more and more "wet film" providers announcing the discontinuation of film production, many countries will be faced with the choice of either moving towards digital sensors or being left without the possibility to independently conduct such missions. The Treaty does of course give States-Parties the possibility to conduct joint missions or rent planes and sensors from other States-Parties, but this is not always possible or affordable in the long run. The next $3-5$ years will be an interesting time within the Treaty with many StatesParties conducting further digital sensor certifications. Most States-Parties will most probably opt for obtaining off the shelf solutions, not custom built sensors like the OSDCAM4060. These will most probably be deemed problematic for Open Skies purposes, for the sole reason that they usually have a very high spatial resolution, which is not sought after in Open Skies.

In addition to major changes occurring within the Open Skies regime from a technical point of view, recent years have also shown quite big changes in the approach of some States-Parties to the Treaty. This has sometimes lead to quite big problems within the Treaty, some of which have been described by Spitzer (2011). 
Due to political nuisances and misinterpretations of the Treaty documents by certain States-Parties, the long distance future of this multinational agreement is unluckily very questionable.

\section{References}

Breitenstein, D., Rogers, G., Roth D. and Huxtable B. (2000). Advanced resolution enhancement techniques for search and rescue. Proc. SPIE 4050. Automatic Target Recognition X, 207 DOI: $10.1117 / 12.395565$

Hexagon Geospatial (2014), Erdas Imagine 2014, Minor Release 1 - Release Notes, (http://www. yourgeo.eu/service-packs/imagine/ERDAS_IMAGINE_Release_Notes_2014-SP1.pdf)

Kapuśniak, T. (2005). The Structure of the Conventional Arms Control Regime in Europe (CFE) [Struktura reżimu o rozbrojeniu konwencjonalnym w Europie (CFE) in Polish]. Annales Universitatis Mariae Curie-Sklodowska, Vol. XII sectio K, 75-98.

Leica ADS80 Datasheet (2011). Airborne Digital Sensor.Digital Airborne Imaging Solution, Leica, Switzerland.

Loce, R. and Dougherty, E. (1997). Enhancement and Restoration of Digital Documents: Statistical Design of nonlinear algorithms, SPIE Press monograph, ISBN 9780819421098

Malvar, H., He, L. and Cutler, R. (2004). High-quality linear interpolation for demosaicing of bayerpatterned color images, ICASSP (http://ieeexplore.ieee.org/stamp/stamp.jsp?tp=\&arnumber=1326587)

Orych, A. (2011). Metodyka prowadzenia analizy wizualnej zobrazowań cyfrowych w celu wyznaczania dopuszczalnej wysokości lotu dla misji Open Skies. Biuletyn WAT, LX(3), 321-334.

Petrie, G. (2008). Systematic Oblique Aerial Photography Using Multiple Digital Cameras, VIII International Scientific \& Technical Conference " From Imagery to Map: Digital Photogrammetric Technologies" September 15-18, 2008 - Porec, Croatia.

Pulujkar, M. and Apte, S. (2013). Demosaicking Images with Motion Blur. Journal of Medical Imaging and Health Informatics, 3(1), 17-21.

Reulke, R., Becker, S., Haala, N. and Tempelmann, U. (2006). Determination and improvement of spatial resolution of the CCD-line-scanner system ADS40, ISPRS Journal of Photogrammetry and Remote Sensing, Volume 60, Issue 2, pp 81-90, doi:10.1016/j.isprsjprs.2005.10.007

Spitzer, H. (2011). Open Skies in turbulence, a well functioning treaty is endangered by outside developments, Security and Human Rights 2011, 4, 103-112.

Treaty on Open Skies (1992), OSCE: http://www.osce.org/library/14127?download=true

Vijayaraghavan, K., Parpyan,i K., Thakwani, S. and Iyengar N. (2009). Methods of Increasing Spatial Resolution of Digital Images with Minimum Detail Loss and its Applications, 5th International Conference on Image and Graphics, Xi'an China. 


\title{
Wkraczając w cyfrowy wiek Traktatu o Otwartych Przestworzach
}

\author{
Agata Orych \\ Wojskowa Akademia Techniczna \\ Wydział Inżynierii Lądowej i Geodezji \\ Instytut Geodezji, Zakład Teledetekcji i Fotogrametrii \\ ul. Kaliskiego 2, 00-908 Warszawa, Polska \\ agata.orych@wat.edu.pl
}

\section{Streszczenie}

Od ponad 20 lat, Traktat o Otwartych Przestworzach pełni rolę narzędzia wspierającego pokój pomiędzy krajami Ameryki Północnej oraz Europy. Porozumienie to opiera się na umożliwianiu każdemu państwu-sygnatariuszowi Traktatu samodzielne wykonywanie lotów obserwacyjnych oraz pozyskiwanie informacji obrazowej na temat terytorium innych Państw-Stron Traktatu. Oryginalnie Traktat zakładał jedynie pozyskiwanie danych obrazowych za pomocą tradycyjnych aparatów fotograficznych na kliszę fotograficzną. Wraz z nagłym rozwojem technologii sensorów cyfrowych, kolejnym logicznym krokiem w przód było dostosowanie zapisów Traktatu, tak aby umożliwić wykorzystanie tego typu sensorów podczas misji obserwacyjnych. Artykuł ten opisusje ten proces przejścia oraz opisuje wybrane problemy techniczne jakie zostały poruszone przez ekspertów pracujących w grupach roboczych Komisji Konsultatywnej Traktatu o Otwartych Przestworzach (KKOP). 